\title{
Use of Lytic Bacteriophages to Reduce Salmonella Enteritidis in Experimentally Contaminated Chicken Cuts
}

\section{DAuthor(s)}

Fiorentin L

Vieira ND

Barioni Júnior W

Embrapa Suínos e Aves

Mail Address

Laurimar Fiorentin

Embrapa Suínos e Aves

BR 153 km 110 - CP 21 - Vila Tamanderá

89.700000 - Concórdia, SC, Brazil

Phone: $\quad+55$ (49) $442-8555$

Fax: $\quad+55(49) 442-8559$

E-mail: laurimar@cnpsa.embrapa.br

\section{Keywords}

Bacteriophages, contamination, Salmonella, poultry, skin.

\section{ABSTRACT}

Reducing Salmonella contamination in poultry is of major importance to prevent the introduction of this microorganism into the food chain. Salmonellae may spread during storage time (shelf life) whenever preharvest control fails or post-harvest contamination occurs. Therefore, preventive measures should also be used in the post-harvest level of poultry production in order to control salmonellae. Chicken skin samples were experimentally contaminated by immersing whole legs (thighs and drumsticks) in a suspension containing $10^{6}$ colony forming units per milliliter (CFU/mL) of Salmonella Enteritidis phage type 4 (SE PT4) at the slaughter day. One day later, samples from one group were immersed in a suspension pool containing $10^{9} \mathrm{CFU} / \mathrm{mL}$ of each of three wild salmonella-lytic bacteriophages previously isolated from feces of freerange chickens. Salmonella counting was performed at three-day intervals in the chicken legs stored at $5^{\circ} \mathrm{C}$ and showed a significant reduction $(\mathrm{P}<0.05)$ of SE PT4 in bacteriophage-treated cuts on days 3, 6 and 9 post-treatment. These findings suggest that the use of bacteriophages may reduce SE PT4 in chicken skin. Further studies are encouraged and might demonstrate the potential of this approach as an efficient and safe technique to be routinelly used for Salmonella control in chicken products.

\section{INTRODUCTION}

Pre-harvest Salmonella elimination might play a significant role in the prevention of pathogen introduction into the food chain and consequently in the reduction of food poisoning in humans (Seo et al., 2000). It is more likely that the pre-harvest control of salmonellae is effective if a multi-factorial program is implemented. Good agricultural practices such as hazard analysis and critical control point (HACCP) (Nayak et al., 2003), vaccination (Zhang-Barber et al., 1999; Yamane et al., 2000), probiotics, prebiotics and symbiotics (Van Immerseel et al., 2002) have been used in poultry production as preventive measures if infection by Salmonella is likely to occur. In spite of that, no measure has been shown to be $100 \%$ effective and salmonellae remain as major contaminants to poultry (Persson \& Jendteg, 1992; Mead et al., 1999). The potential of phage therapy for Salmonella control has been recently assessed in the pre-harvest level of poultry production (Fiorentinn et al., 2005; Sklar et al., 2001).

Decontamination of chicken skin has been of major interest in applied research. Some chemical and physical procedures have been tested, such as carcass washing with aqueous solution of lactic acid (Xiong et al., 1998), use of calcium hypochlorite, hydrogen peroxide and radiation (Nassar et al., 1997), air chilling (Allen et al., 2000), chlorine and sodium triphosphate (Xiong et al., 1998; Whyte et al., 2001), as well as the use 
of natural products such as grapefruit seed extract (Xiong et al., 1998). However, it has not been developed an efficient method that is completely devoid of chemicals and that might not cause food safety concerns.

In a previous study, we isolated and characterized Salmonella-lytic bacteriophages (Fiorentin et al., 2004). Some of these bacteriophages have been administered in vivo to SE PT4-infected broilers and there was a reduction in the colony forming units of SE PT4 per gram of cecal contents by 3.5 orders of magnitude (Log CFU/g) (Fiorentin et al., 2005). Other authors have also successfully reported reductions in Salmonella counts by using bacteriophages in chicken internal organs and feces (Toro et al., 2005), skin (Goode et al., 2003) or poultry products (Whichard et al., 2003). The positive results led to the hypothesis that the bacteriophage isolated previously in our laboratory might also be efficient in reducing SE PT4 in chicken skin. Some advantages of administering phages onto the skin of poultry carcasses are that phages would not recycle in the host and therefore selection of resistant strains would be avoided. Besides, methods of biological control pose fewer risks to the consumer compared to chemical methods.

In the present study, chicken thighs and drumsticks were contaminated with SE PT4 and later treated with a panel of salmonellae-lytic bacteriophages isolated from free-range chickens.

\section{MATERIAL AND METHODS}

\section{Chicken thighs and drumsticks}

The study evaluated three groups as described in Table 1. The groups were comprised of 25 whole legs (thighs and drumsticks) with mean weight between 300 and 350 grams. The legs were collected during slaughter of a Salmonella-negative flock previously monitored using drag swabs (Waltman et al., 1998). Chicken cuts (or parts) were experimentally contaminated by immersion in a suspension of phosphate buffered saline (PBS pH7.2) containing $10^{6}$ CFU/mL of SE PT4 and allowed to dry for a few minutes. The samples of the three groups were transferred to sterile plastic bags, sealed and kept at $5^{\circ} \mathrm{C}$. Afterwards, five samples per treatment were randomly taken at each three days for Salmonella and bacteriophage counts.

\section{Contamination with Salmonella}

SE PT4 isolate P125589 was kindly provided by Dr
Paul Barrow (ARFC Institute for Animal Health, Houghton Laboratory, Cambridge, England). It was originally isolated by Dr B. Rowe (Central Public Health Laboratory, London, UK) from a case of human food poisoning (Barrow \& Lovell, 1991).

A fresh colony of SE PT4 was inoculated into $10 \mathrm{~mL}$ of nutrient broth (NB, 1 $\mathrm{g} / \mathrm{L}$ beef extract, $2 \mathrm{~g} / \mathrm{L}$ yeast extract, $5 \mathrm{~g} / \mathrm{L}$ peptone, $5 \mathrm{~g} / \mathrm{L}$ sodium chloride, $\mathrm{pH} 7.0$ ) and incubated overnight at $37^{\circ} \mathrm{C}$ under shaking (200rpm). The culture was frozen at $-80^{\circ} \mathrm{C}$ and one aliquot was used for enumeration of viable cells, by counting colonies grown from tenfold dilutions streaked onto nutrient agar and incubated for $24 \mathrm{~h}$ at $37^{\circ} \mathrm{C}$. After counting, the original culture was diluted with sterile buffered saline $(1 \mathrm{~L})$ to produce a solution containing $10^{6} \mathrm{CFU} / \mathrm{mL}$ that was used to contaminate the chicken cuts.

\begin{tabular}{|c|c|c|}
\hline Group & & \\
\hline 1 & & Non-rientaminated and non-treated \\
\hline 2 & 25 & $\begin{array}{l}\text { Contaminated by immersion on a suspension } \\
\text { containing } 10^{6} \mathrm{CFU} / \mathrm{mL} \text { of Salmonella } \\
\text { Enteritidis phage type } 4 \text { at slaughter day }\end{array}$ \\
\hline 3 & 25 & $\begin{array}{l}\text { Contaminated as in group } 2 \text {, treated } \\
\text { one day later by immersion in a suspension } \\
\text { containing } 10^{9} \mathrm{PFU} / \mathrm{mL} \text { of a mixture of } \\
\text { bacteriophages CNPSA1, CNPSA3 and } \\
\text { CNPSA4 }\end{array}$ \\
\hline
\end{tabular}

\section{Treatment with bacteriophages}

Bacteriophages CNPSA 1, CNPSA3 and CNPSA4 were isolated from feces of free-range chickens in Brazil and characterized as described elsewhere (Fiorentin et al., 2004). Since resistance to bacteriophages may emerge in growing populations of bacteria, we decided to use a pool of three different viruses. Frozen bacteriophage stocks were amplified on overlay cultures of SE PT4 prepared with Nutrient Broth (NB) containing $0.7 \%$ agarose. Enough bacteriophage particles were then used to inoculate one liter of SM buffer $(5.8 \mathrm{~g} / \mathrm{L} \mathrm{NaCl}, 2.0 \mathrm{~g} / \mathrm{L} \mathrm{MgSO} 4$ $7 \mathrm{H} 2 \mathrm{O}, 5.0 \mathrm{~mL} / \mathrm{L}$ of a $5 \%$ solution of gelatin, $50 \mathrm{~mL} / \mathrm{L}$ of $1 \mathrm{M}$ Tris- $\mathrm{HCl} \mathrm{pH} \mathrm{7.5)} \mathrm{to} \mathrm{a} \mathrm{concentration} \mathrm{of} 10^{9}$ plaque forming units per milliliter (PFU/mL), which results in a multiplicity of infection of 1,000 (MOI: 1,000), i.e., a thousand PFU of bacteriophages per CFU of SE PT4 was used to contaminate the chicken parts. Bacteriophage titers were determined using tenfold dilutions of the virus preparation mixed to SE PT4 in log-phase growth $(10 \mu \mathrm{L}: 250 \mu \mathrm{L})$. The mixtures were 
incubated at $37^{\circ} \mathrm{C}$ for 20 minutes and then mixed with $7 \mathrm{~mL}$ of melted $\mathrm{NB}$-agarose $\left(45^{\circ} \mathrm{C}\right)$, thoroughly homogenized and overlaid onto $10 \mathrm{~cm}$-diameter Nutrient Agar plates (NB added with $15 \mathrm{~g} / \mathrm{L}$ bacteriologic agar) (Kudva et al., 1999). Plaques of lysis were counted after incubation for 24 hours at $37^{\circ} \mathrm{C}$. Bacteriophage titers were obtained by multiplying the number of plaques in each dilution by the dilution factor. Cuts were immersed in the bacteriophage suspension, allowed to dry for a few minutes and replaced into the plastic bag for storage at $5^{\circ} \mathrm{C}$ for 15 days.

\section{Experimental design}

The number of washable viable Salmonella cells and bacteriophage particles were assessed in five leg samples taken from each group at three-day intervals. The cuts were randomly chosen and submitted to Salmonella and bacteriophage assessment as described below.

\section{Salmonella isolation}

Samples from Groups 2 and 3 were individually rinsed in sterile plastic bags containing $100 \mathrm{~mL}$ of buffered peptone water. The number of Salmonella colony forming units (CFU) in the rinse solution (rinse peptone water) was determined by multiplying the number of viable cells in $1 \mathrm{~mL}$ of the solution multiplied by 1,000 . Rinse peptone water was diluted tenfold in buffered saline and $100 \mu \mathrm{L}$ of each dilution were spread onto $10 \mathrm{~cm}$-diameter brilliant green agar plates (BGA) supplemented with novobiocin $(40 \mu \mathrm{g} / \mathrm{mL})$ and incubated at $37^{\circ} \mathrm{C}$ for $48 \mathrm{~h}$. Salmonella CFU per cut was determined by the number of colonies in plates with 30 to 300 colonies multiplied by the dilution factor. The theoretical limit of detection of this method is $30 \mathrm{x}$ $10^{2}$ CFU per cut, which means that negative results in Groups 2 and 3 would actually represent $<3,000$ CFU per cut. Slight pink-white opaque colonies surrounded by red medium grown on BGA were confirmed as Salmonella by slide agglutination test with polyvalent anti-somatic serum.

Cuts from all groups were also submitted to qualitative analysis of Salmonella. Rinse peptone water was incubated at $37^{\circ} \mathrm{C}$ for $24 \mathrm{~h}$ for pre-enrichment. Afterwards, $0.3 \mathrm{~mL}$ of each culture was enriched in $2.7 \mathrm{~mL}$ of Rappaport-Vassiliadis Soya peptone broth (RVS) and incubated at $42^{\circ} \mathrm{C}$ for $24 \mathrm{~h}$. A loopful was then streaked onto $B G A$ plates and incubated at $37^{\circ} \mathrm{C}$ for $24 \mathrm{~h}$. Salmonella colonies were identified as described above.

\section{Bacteriophage titering}

Cuts from Group 3 were individually rinsed in $100 \mathrm{~mL}$ of SM buffer and total bacteriophage PFU was titered as follows. One milliliter of rinse SM buffer was treated with $5 \%$ chloroform to lyse all cells and $10 \mu \mathrm{L}$ were serially diluted tenfold in sterile SM buffer. From each dilution, $10 \mu \mathrm{L}$ were then mixed with $250 \mu \mathrm{L}$ of SE PT4 in log-phase growth and incubated for 20 minutes at $37^{\circ} \mathrm{C}$ to allow infection of Salmonella cells by bacteriophages. Afterwards, mixtures were added to $7 \mathrm{~mL}$ of NB containing $0.7 \%$ agarose, thoroughly homogenized and overlaid onto $10 \mathrm{~cm}$-diameter nutrient agar plates, which were then incubated for $24 \mathrm{~h}$ at $37^{\circ} \mathrm{C}$. Plaques of lysis were counted on the cultures with 30 to 300 plaques. The number of bacteriophages was determined by multiplying the number of plaques by 100 and expressed as total PFU per $\mathrm{mL}$. Total PFU per chicken cut was obtained multiplying total PFU by 100 .

Cuts from Groups 1 and 2 were submitted to qualitative analysis to confirm their bacteriophage-free status. One milliliter of rinse SM buffer from each chicken cut was treated with $5 \%$ chloroform, vortexed, centrifuged $(12,000 \times \mathrm{g}$ for 4 minutes) and $100 \mu \mathrm{L}$ of the supernatant was added to $900 \mu \mathrm{L}$ of a SE PT4 culture, which was incubated at $37^{\circ} \mathrm{C}$ for $24 \mathrm{~h}$. After incubation, this preparation was also treated with $5 \%$ chloroform to lyse all bacteria, centrifuged and $10 \mu \mathrm{L}$ of the supernatant was used to prepare overlaying SE PT4 cultures as described before. Positive results were identified by the presence of lysis plaques with about $1 \mathrm{~cm}$ of diameter on the Salmonella lawn.

\section{Statistical analysis}

Analysis of variance followed by t-test was used to compare means of CFU of SE PT4 per piece according to the experimental design. Statistical analysis was performed using a commercial package (SAS, 2001).

\section{RESULTS AND DISCUSSION}

\section{Salmonella isolation}

SE PT4 was recovered from all cuts in all five assessments using the samples of rinse peptone water from Group 2 and Group 3 submitted to selective enrichment. Sampling was performed at each three days after treatment until day 15 (except for day 3). Therefore, the results indicate a relative long period of SE PT4 survival considering the shelf life of refrigerated products. Survival for long periods has been recognized 
as an important feature of salmonellae; even in low temperatures, salmonellae were able to survive in nonsanitized poultry carcasses at least for 26 days (Thomson et al., 1979).

The presence of SE PT4 in the bacteriophagetreated cuts indicates that the conditions used in this study did not allow bacteriophages to eliminate Salmonella from poultry skin. However, it is unlikely that any single technique applied to poultry carcasses would remove Salmonella completely from the skin, nor would Salmonella be naturally removed from contaminated skin only by refrigeration. We have previously reported that bacteriophages orally administered to SE PT4-infected broilers reduced the numbers of Salmonella significantly, but could not remove completely the bacteria from chicken cecae (Fiorentin et al., 2005). The same is probably also true in other situations, such as when bacteriophages are applied to poultry skin. In regard to food safety, it is extemely important to develop techniques that completely prevent food poisoning in humans. However, it seems hard to achieve this objective using only a single technique and bacteriophages should probably be used together with other methods to completely remove Salmonella from chicken skin. The present study is our first evidence of Salmonella reduction in chicken skin by the use of bacteriophages. The findings encourage us to perform further research in order to achieve more efficiency regarding bacteriophage treatment applied on SE PT4-contaminated cuts.

\section{Bacteriophage isolation}

Rinse peptone water from cuts from Groups 1 and 2 were inoculated with SE PT4 to permit bacteriophage amplification, in case they were present. This qualitative analysis confirmed the bacteriophage-free status of both groups. On the other hand, bacteriophages were isolated from all pieces from Group 3 in all five samplings according to the qualitative analysis. These results indicate that bacteriophages were not removed from broiler skin contaminated with Salmonella within a 15 day-period, which might have resulted from bacteriophage multiplication on the bacteria or because bacteriophages were not inactivated by natural components of the chicken skin.

A panel of three bacteriophages was used to avoid selection of strains of SE PT4 resistant to a particular virus. Although this was a necessary approach, it prevented us from knowing whether one specific bacteriophage lasts longer in the cuts or if the three of them have been recovered from all samples at the same magnitude. However, we have previously reported that the three bacteriophages share similar lytic properties and multiplication rates when cultured in SE PT4 (Fiorentin et al., 2004) and this might also occur in vivo.

\section{Salmonella counting}

Enumeration of Salmonella was performed only on samples from Group 2 and Group 3, because Group 1 was not contaminated and yielded negative results in the qualitative analysis throughout the experiment. Total CFU ranged from $0.66 \pm 0.05 \times 10^{8}$ CFU to 4,840 $\pm 461.09 \times 10^{8} \mathrm{CFU}$ per cut in the first and last sampling of Group 2 (SE PT4 contaminated group), respectively. In the SE PT4-contaminated and bacteriophagetreated cuts (Group 3), total CFU was $0.29 \pm 0.08 \times$ $10^{8} \mathrm{CFU}$ and $3,920 \pm 738.51 \times 10^{8} \mathrm{CFU}$ per cut in the first and the last sampling days, respectively. There was an increasing trend in total CFU in groups of samples taken at each three days. These concentrations of CFU were high, and may be explained because of the high CFU dose used to contaminate the pieces and also because the experimental conditions prevented competition between Salmonella and other organisms (Coleman et al, 2003). However, lower magnitudes of total CFU were seen in the bacteriophage-treated group (Group 3) at all sampling days, except for 12 and 15 days post-treatment (Table 2 and Figure 1). The means of treated and non-treated parts were compared by t-test (SAS, 2001), and $P$ values were highly significant on days 3,6 and 9, indicating higher efficiency of bacteriophages in reducing Salmonella CFU within a 9-day period (Table 2).

Salmonella numbers in samples from Group 2 were of lower magnitude at 12 days post-inoculation compared to the samples of Group 3 or even to the samples of Group 2 in the previous samplings. This result was probably caused by a technical variation that occurred during dilution or plating. Therefore, we suppose that bacteriophages might have actually had an effect for longer than 9 days. It is also possible, however, that Salmonella contamination was lower or bacteriophage effects were greater in the chicken cuts randomly sampled as one group on day 12 . The curve presented in Figure 1 suggests that the data of Group 2 on day 12 should logically fall between 4,000 and $8,000 \times 10^{8} \mathrm{CFU}$.

Reduction of CFU on treated cuts was about 4.49 times on day 9 post-treatment (Table 2). Such a reduction is enough to demonstrate a cause-and-effect relationship, but additional research is required in order 


\begin{tabular}{|c|c|c|c|c|}
\hline Days after treatment & Group 2* & Group 3 & P value** & Reduction*** \\
\hline 3 & $0.66 \pm 0.05$ & $0.29 \pm 0.08$ & 0.0334 & 2.27 \\
\hline 6 & $340.2 \pm 124.16$ & $74.6 \pm 20.37$ & 0.0026 & 4.56 \\
\hline 9 & $7,734 \pm 2,875.02$ & $1,720 \pm 360.85$ & 0.0195 & 4.49 \\
\hline 12 & $772 \pm 51.52$ & $1,714 \pm 813.74$ & 0.269 & -0.45 \\
\hline 15 & $4,840 \pm 461.09$ & $3,920 \pm 738.51$ & 0.552 & 0.97 \\
\hline
\end{tabular}

${ }^{*}$ Non-contaminated and non-treated pieces (Group 1) were negative throughout the experiment. ${ }^{*}$ t-test. ${ }^{* *}$ Difference in mean values between Group 3 (contaminated, treated) and Group 2 (contaminated, non-treated).

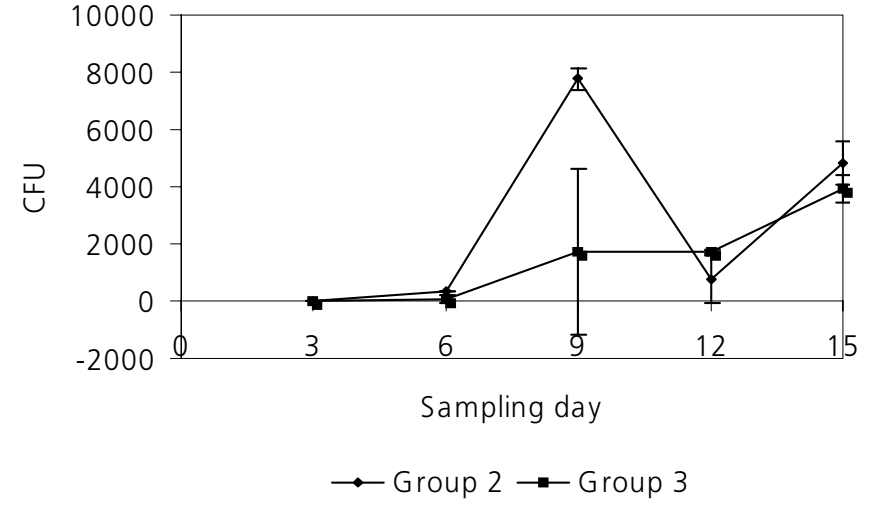

Figure 1 - Mean \pm standard deviation of total colony forming units (CFU $\times 10^{8}$ ) of SE PT4 recovered from cuts contaminated with Salmonella (Group 2) or contaminated and treated with bacteriophage (Group 3). Differences between means were statistically significant on days 3,6 and 9 .

to achieve Salmonella reduction by several orders of magnitude. Goode et al. (2003) carried out a research with the same SE PT4 strain used in the present study and reported that a bacteriophage used for phage typing have also not reduced CFU by several orders of magnitude. Since those authors used a different technique and bacteriophage efficiency assessment was performed only over a $48 \mathrm{~h}$-experimental period, any direct comparison between the two experiments would not be adequate. Nevertheless, based on the results from the present study and those reported by Goode et al. (2003), it seems reasonable to assume that additional research is necessary to better understand how bacteriophages can be used more efficiently to reduce Salmonella in chicken skin.

The fact that total CFU increased even in treated cuts leads us to suppose that higher concentrations of bacteriophages might prevent such multiplication of SE PT4 on the skin. However, this is our first report on the use of bacteriophages to reduce Salmonella presence in poultry skin. The convincing results presented herein encourage further research in order to achieve greater reductions in contamination of poultry carcasses or cuts by Salmonella. The use of higher concentrations of bacteriophages, either alone or coupled with other methods, might determine more efficient reductions of SE PT4 contamination of poultry skin.

\section{Enumeration of bacteriophages}

Concentration of bacteriophages recovered from the rinse water in Group 3 ranged from 5.8 to 25.4 x $10^{5} \mathrm{PFU}$ per cut (Table 3 ). The observed variation is probably inherent to the technique used for titering the viruses, once the difference between titers were still smaller than one order of magnitude. This is a low recovery rate compared to the concentration of bacteriophage $(10 \% / \mathrm{mL})$ used to treat the cuts contaminated with SE PT4. A possible explanation is that only a small portion of SM buffer might have actually remained in the cuts after dipping or perhaps bacteriophages adhered poorly to components on the chicken skin; both conditions would have resulted in lower $\mathrm{MOI}$ than the expected $\mathrm{MOI}$ of 1,000. However, it is noteworthy that bacteriophages were viable and showed similar titers for 15 days at $5^{\circ} \mathrm{C}$ even in contact with chicken skin.

\begin{tabular}{cc}
\hline Table 3 - Means of total plaque forming units (PFU) of \\
bacteriophages recovered from rinse peptone water of \\
contaminated and treated cuts (Group 3). \\
Days after treatment & Total PFU recovered per cut* \\
3 & $15 \times 10^{5}$ \\
6 & $5.8 \times 10^{5}$ \\
9 & $25.4 \times 10^{5}$ \\
12 & $8.4 \times 10^{5}$ \\
15 & $13 \times 10^{5}$ \\
\hline
\end{tabular}

* Obtained by tittering $10 \mu \mathrm{l}$ of rinse solution multiplied by the dilution factor.

The fact that bacteriophage titers did not increase in Group 3 might have been caused by the reduction observed on CFU of SE PT4. It is also possible that these 
bacteriophages did not target any other bacteria present on the chicken skin, otherwise they would have shown higher PFU per cut with longer shelf storage time.

\section{CONCLUSIONS}

A panel of bacteriophages reduced SE PT4 countings in experimentally contaminated chicken parts stored at $5^{\circ} \mathrm{C}$. We demonstrated that Salmonella CFU was reduced in the bacteriophage-treated cuts on days 3, 6 and 9 post-treatment when compared to their non-treated counterparts.

\section{REFERENCES}

Allen VM, Corry JE, Burton CH, Whyte RT, Mead GC. Hygiene aspects of modern poultry chilling. International Journal of Food Microbiology 2000; 58:39-48.

Barrow PA, Lovell MA. Experimental infection of egg-laying hens with Salmonella enteritidis phage type 4. Avian Pathology 1991; 20:335-348.

Coleman ME, Sandberg S, Anderson SA. Impact of Microbial Ecology of Meat and Poultry Products on Predictions from Exposure Assessment Scenarios for Refrigerated Storage. Risk Analysis 2003; 23:215-228.

Fiorentin L, Vieira ND, Barioni Júnior W. Oral treatment with bacteriophages reduces the concentration of Salmonella Enteritidis PT4 in cecal contents of broilers. Avian Pathology 2005; 34(3):1-6.

Fiorentin L, Vieira ND, Barioni Júnior W, Barros S. In vitro characterization and in vivo properties of Salmonellae lytic bacteriophages isolated from free-range chickens. Brazilian Journal of Poultry Science 2004; 6:105-112.

Goode D, Allen VM, Barrow PA. Reduction of experimental Salmonella and Campylobacter contamination of chicken skin by application of lytic bacteriophages. Applied Environmental Microbiology 2003; 69:5032-5036.

Kudva IT, Jelacic S, Tarr PP, Youderian P, Hovne CJ. Biocontrol of Escherichia coli 0157 with 0157-Specific bacteriophages. Applied and Environmental Bacteriology 1999; 65:3767-3773.

Mead PS, Slutsker L, Dietz V, McCaig LF, Bresee JS, Shapiro C, Griffin PM, Tauxe RV. Food-related illness and death in the United States. Emerging Infectious Diseases 1999; 5(5):607-625.

Nassar TJ, al-Mashhadi AS, Fawal AK, Shalhat AF. Decontamination of chicken carcasses artificially contaminated with Salmonella. Revue Scientifique et Technique 1997; 16(3):891-7.

Nayak R, Kenney PB, Keswani J, Ritz C. Isolation and characterization of Salmonella in a turkey production facility. British Poultry Sciences 2003;44(2):192-202.
Persson $U$, Jendteg $S$. The economic impact of poultry-borne salmonellosis: how much should be spent on prophylaxis? International Journal of Food Microbiology 1992; 15(3-4):207-213.

SAS Institute. System for Microsoft Windows, Release 8.2. Cary, North Carolina, USA; 1999-2001. CD-ROM.

Seo KH, Holt PS, Gast RK, Hofacre CL. Elimination of early Salmonella enteritidis infection after treatment with competitive-exclusion culture and enrofloxacin in experimentally infected chicks. Poultry Sciences 2000; 79:1408-1413.

Sklar IB, Joerger RD. Attempts to utilize bacteriophage to combat Salmonella enterica serovar Enteritidis infection in chickens. Journal of Food Safety 2001; 21:15-29.

Thomson JE, Bailey JS, Cox NA. Phosphate and heat treatments to control Salmonella and reduce spoilage and rancidity on broiler carcasses. Poultry Sciences 1979; 58:139-143.

Toro H, Price SB, McKee AS, Hoerr FJ, Krehling J, Perdue M, Bauermeister $L$. Use of bacteriophages in combination with competitive exclusion to reduce Salmonella from infected chickens. Avian Diseases 2005; 49(1):118-24.

Van Immerseel F, Cauwerts K, Devriese LA, Haesenbrouck F, Ducatelle R. Feed additives to control Salmonella in poultry. World's Poultry Science Journal 2002; 58:501-513.

Waltman WD, Gast RK, Mallinson ET. Salmonellosis. In: Swayne de, editor. A laboratory manual for the isolation and the identification of avian pathogens. $4^{\text {th }}$ ed. Kennett Square: The American Association of Avian Pathologists; 1998. p.4-13.

Whichard JM, Sriranganathan N, Pierson FW. Suppression of Salmonella growth by wild-type and large-plaque variants of bacteriophage Felix 01 in liquid culture and on chicken frankfurters. Journal of Food Protection 2003; 66(2):220-225.

Whyte P, Collins JD, McGill K, Monahan C, O’Mahony H. Quantitative investigation of the effects of chemical decontamination procedures on the microbiological status of broiler carcasses during processing. Journal of Food Protection 2001; 64(2):179-183.

Xiong H, Li Y, Slavik MF, Walker JT. Spraying chicken skin with selected chemicals to reduce attached Salmonella typhimurium. Journal of Food Protection 1998; 61:272-275.

Yamane Y, Leonard JD, Kobatake R, Awamura N, Toyota Y, Ohta H, Otsuki K, Inoue T. A case study on Salmonella enteritidis(SE) origin at three egg-laying farms and its control with an $S$. enteritidis bacterin. Avian Diseases 2000; 44(3):519-526.

Zhang-Barber L, Turner AK, Barrow PA. Vaccination for control of Salmonella in poultry. Vaccine 1999; 17:2538-2545. 